\title{
Hybrid accountants in the age of the business partner: exploring institutional drivers in a mining company
}

\author{
Bo Karlsson $^{1}$ (D) Anders Hersinger ${ }^{1} \cdot$ Monika Kurkkio $^{1}$
}

Published online: 13 April 2019

(c) The Author(s) 2019

\begin{abstract}
This paper addresses the question of how it is possible, despite the persuasive characteristics of the business partner role, to explain the prevalence of hybrid accountants in management accounting practice. This research question is addressed from an institutional theory vantage point, suggesting that institutional drivers exist in every organization that shape the role of the practicing actors. The empirical evidence presented is drawn from a case study of a mining company pursuing a change program to transform its management accountants into business partners. The results illustrate how the hybrid accountant role is formed through an interplay among regulative, normative, and cognitive institutional drivers that influence the role of the management accountants in opposing directions. Because of the tension between facilitating and impeding institutional drivers, the change program toward business partnering results in a hybrid accountant role which is characterized by a combination of traditional and business partner traits. Hence, the conclusions suggest that the prevalence of hybrid accountants in management accounting practice can be explained by tensions between opposing institutional drivers that contribute to a compound role.
\end{abstract}

Keywords Hybrid accountant · Business partner · Management accountant $\cdot$ Role . Institutional drivers · Case study

\section{Introduction}

Management accountants, sometimes described as business partners, are important actors in charge of financial information (Jönsson 2009) and play a critical role as advisors in managerial decisions (Goretzki 2013). In both theory and practice, a business partner is supposed to have moved beyond traditional and rational

Bo Karlsson

bo.karlsson@1tu.se

1 Department of Business Administration, Technology and Social Sciences, Accounting and Control, Luleå University of Technology, 97341 Luleå, Sweden 
management accounting techniques to become a capable provider of rich, forwardlooking information for strategic decisions (Granlund and Lukka 1998; Emsley 2005; Baldvinsdottir et al. 2009). The notion of the business partner remains a popular template for practicing management accountants and a vibrant stream of literature in academic business research (Rieg 2018). Indeed, research shows that employers hire management accountants based on business partner characteristics (Lepistö and Ihantola 2018), possibly as a result of their social orientation and their emphasis on communication and interaction rather than rational technical skills (Lepistö and Ihantola 2018).

Researchers point out that the cultural norms of organizations today work in favor of management accountants with an aptitude for business partnering (see Järvenpää 2007; Endenich 2014). Management accountants need to work in social networks across hierarchal levels in organizations (Vaivio and Kokko 2006; Jönsson 2009; Weber 2011; Cieslak 2011). Moreover, the decentralization of organizations and the rise of modern information technology require accountants to be versed in communication and equipped with a rich understanding of operations in the organizations where they are employed (e.g., Granlund and Lukka 1997; Burns and Baldvinsdottir 2005; Järvenpää 2007; Hyvönen et al. 2015). Because contemporary management accounting work is not strictly homogenous and situations can vary, practicing management accountants must be able to diagnose each situation to determine how to act appropriately (Baxter and Chua 2009, p. 66; Jönsson 2009). In sum, a rich body of research provides clues as to why the business partner has become a much desired ideal in the business practice of contemporary organizations.

To the business partner, management accounting means more than scorekeeping and delivering aggregated financial information to top management. Rather, the business partner is characterized as a management-oriented and value-added internal consultant of sorts (Burns and Vaivio 2001; Järvenpää 2007; Goretzki et al. 2013). In this capacity, the business partner fulfills a valuable coordinating role between top management and operational actors within the organization. Studies have shown that the business partner strengthens the decision-making relevance of financial information to top management by improving collaboration with operational managers (Byrne and Pierce 2007; Pietrzak and Wnuk-Pel 2015). Apparently, the business partner is capable of communication, team-building, and conflict resolution and skilled at motivating and negotiating with others (Burns and Baldvinsdottir 2005; Vaivio and Kokko 2006).

Despite the theoretical and practical interest in the business partner, empirical research has found that the traditional scorekeeping orientation coexists with business partner traits among practicing management accountants, suggesting that the role has broadened (Friedman and Lyne 1997; Granlund and Lukka 1998; Byrne and Pierce 2007). Such empirical evidence points to a hybrid accountant with some business partner characteristics (Burns and Baldvinsdottir 2005; Weber 2011; Graham et al. 2012; Lambert and Sponem 2012). Hence, the hybrid accountant can be seen as a step toward the role of a business partner but not a complete transformation (Mouritsen 1996; Granlund and Lukka 1997; Rieg 2018). In contrast to the business partner, the hybrid accountant does not sacrifice the traditional and hierarchical stewardship role (Byrne and Pierce 2007). Neither 
does he or she participate to the same extent in managerial processes or in management teams (Zainuddin and Sulaiman 2016).

This paper seeks to address the question of how it is possible, despite the persuasive characteristics of the business partner role, to explain the prevalence of hybrid accountants in management accounting practice. For two reasons, this question is addressed from an institutional theory vantage point. First, institutional change theory posits that isomorphic pressures toward the reproduction of established structures tend to work against hybridization, thereby making it interesting to explore the emergence of hybrid forms (Battilana et al. 2017, p. 139). Second, previous research based on an institutional entrepreneurship framework suggests that normative institutional drivers influence the role of the management accountant and its change (Hyvönen et al. 2015). Institutional boundaries within organizations allow a work-related social interplay that shapes the roles of practicing actors (Barley and Tolbert 1997). This suggests that unique institutional drivers exist in every organization, shaping the role of its actors (DiMaggio and Powell 1983; Scott 2013, p. 64; Goretzki et al. 2013).

The research question addressed in this paper is also in line with suggestions in the literature for more research on how the role of management accountants is socially constructed and institutionalized through a complex relationship between management accountants and other organizational actors (Hyvönen et al. 2015; Windeck et al. 2015).

The empirical results of the paper are based on an interpretive case study carried out in a Swedish multinational mining company. We use an interpretive research approach because it is suitable when trying to provide a plausible explanation of a specific and appropriately defined subject like the existence of hybrid accountants in times characterized by a business partner ideal (Lukka 2014). The case study is conducted in the capital-intensive, uncertain, and risky mining industry as this industry represents a challenging setting where the management accountant role can be subject to pressures from different stakeholders and other actors (Bhappu and Guzman 1995; PWC 2012). The selected Swedish multinational mining company is suitable for this study because of its explicit promotion of the business partner role and because of the delineation of controlling from its accounting function.

In this paper, we contribute to management accounting theory by identifying explanatory institutional drivers behind the existence of hybrid accountants in a business partner context. We also contribute to the management accounting literature by providing insights into the development of the role of management accountants in the mining industry, the latter representing a previously under-researched empirical domain.

The paper is organized as follows. In the next chapter, previous research addressing the development of the role of management accountants from an institutional point of view is reviewed. Scott's (2013) framework of institutional pillars and the adaptation of that framework to change management by Palthe (2014) are then introduced. Thereafter, the third chapter presents the research methods, including the research context, choice of case study organization, data collection methods, and interpretations. Next, the empirical results of the study are presented and analyzed. 
The final chapter provides the conclusions of the paper, its contributions and limitations, and recommendations for future research.

\section{Institutionalization of the role of management accountant}

\subsection{Overview of the business partner and hybrid accountant literature}

Traditionally, the management accountant role involves the tasks and responsibilities of using information from control systems to monitor the performance of single individuals, departments, or entire organizations to fulfill preset goals and strategies (Friedman and Lyne 1997; Coad 1996; Tuomela 2005). This role is related to meticulousness, appreciation of formal structures, conservativeness, being methodical (Byrne and Pierce 2007), and reliance on professional norms associated with technical accounting skills (Byrne and Pierce 2007). Hence, less emphasis is placed on interpersonal and communication abilities (Mouritsen 1996; Coad 1996). Adherence to strict rules can be problematic under conditions of uncertainty (Tessier 2014) and therefore insufficient in modern dynamic organizations (Burns and Baldvinsdottir 2005; Broadbent and Laughlin 2009). Accordingly, many would argue that the business partner role potentially is more appropriate in contemporary business (Linsley and Linsley 2014; Chenhall and Moers 2015).

In the management accounting literature, the business partner role is related to a change from the traditional role of the accountant, focusing mostly on technical skills, toward business-orientation, strategic capabilities, and social skills (Jönsson 2009; Linsley and Linsley 2014). Arguably, one reason for this change is the introduction of ideas like the balanced scorecard, leading to less cybernetic management accounting systems (e.g., Linsley and Linsley 2014; Chenhall and Moers 2015). Under such conditions, management accountants must be able to work together with, and develop an understanding of, actors whose main areas of expertise lie outside the accounting territory (Weber 2011). Becoming a business partner involves new tasks and responsibilities that extend beyond the recording and analysis of historically anchored financial information (Weber 2011). A business partner should provide relevant, strategic, and future-oriented information (Yazdifar and Tsamenyi 2005; Weber 2011; Järvenpää 2009), working closely together with management and participating in decision-making (Järvenpää 2007; Goretzki et al. 2013; Hyvönen et al. 2015). Being a business partner means handling situations as they occur where the timing and tactics of how financial information is used are crucial (Goretzki et al. 2018).

Research regarding the business partner concept is ongoing alongside studies on the hybrid accountant. Often the hybrid accountant literature reports that traditional management accounting remains an important part of management accountants' everyday work. Thus, findings in this stream of literature suggest that it is not a matter of the management accountant transitioning to a business partner role but rather a merger of the management accountant's new business orientation and traditional management accounting work (i.e., a hybrid accountant) (Mouritsen 1996; Burns and Baldvinsdottir 2005; Graham et al. 2012). Although researchers do not 
necessarily agree fully about what constitutes a hybrid accountant, this role is often depicted as a balancing act between functional responsibilities and facilitation of managerial decision-making in an advisory capacity (Maas and Matejka 2009; Lambert and Sponem 2012).

In sum, evidence is mounting that it may be overly simplistic to claim that the management accountant role is transitioning into that of a business partner and that hybrid accountants are responsible for a range of operational and strategic tasks (Rieg 2018). Hybrid accountants are involved in team processes and produce value by customizing financial information to fit various organizational actor groups (Byrne and Pierce 2007). However, their work is fundamentally associated with internal analysis, risk management, and scorekeeping (De Loo et al. 2011). Thus, the hybrid accountant combines accounting knowledge with an understanding of business processes, products, and markets (Windeck et al. 2015).

\subsection{Institutional drivers and the role of the management accountant}

Institutional theory suggests that institutional drivers identify and shape actors' roles and their appropriate activities (Burns and Scapens, 2000). The institutional drivers of roles are also connected to recruitment, training, and areer planning (Järvenpää 2007; Goretzki et al. 2013). Scott (2013) proposes that actor roles are shaped by the conceptions of appropriate goals and activities of the actors in their specified social positions (p. 64). Thus, several institutional drivers shape the management accountant role. It is therefore imperative for management accountants to ask themselves in their context what their appropriate role is and adjust accordingly.

Previous research in the management accounting field recognizes that institutional drivers influence development of the management accountant role (e.g., Yazdifar and Tsamenyi 2005). In particular, several drivers of the business partner role have been identified in previous research. Beginning at an environmental level, Halbouni and Nour (2013) explain the significance of globalization for the evolution of the business partner role. In turn, decentralization appears to be an important driver of this development. Because of decentralization, management accountants are required to foster communication skills and learn to understand the operational reality of business firms (Järvenpää 2007; Halbouni and Nour 2013). Relatedly, the introduction of "new" management accounting technologies over the last 30 years has made it necessary for management accountants to adapt and learn how to work in a more business-oriented fashion (Endenich 2014). The rise of modern information technology in the form of integrated systems has also pushed management accountants to learn about operations and to interact with different actors in a wide, cross-sectional, and cooperative manner (Halbouni and Nour 2013).

Other drivers from previous research are also identifiable. Importantly, the notion of the business partner is associated with characteristics and values that tend to be viewed in positive ways in contemporary society. In other words, cultural organizational norms support the development of a cooperating, problem-solving, and change-oriented management accountant (e.g., Järvenpää 2007; Endenich 2014; Hiller et al. 2014). Top management expectations also tend to favor the business 
partner role, and a development in this direction can be facilitated by empowering the management accountants to take on such a role (e.g., Windeck et al. 2015; Eskenazi et al. 2016). Task changes requiring a strategic dimension (i.e., customer orientation) can also in themselves be seen as drivers that pull management accountants into business partnering (Vaivio and Kokko 2006; Jönsson 2009; Weber 2011).

Possibly as a consequence of the norms and expectations described above, business partner characteristics seem in many cases to be advantageous in management accountant recruitment processes, thus indicating the presence of such preferences in the selection strategies of human resource departments (Lepistö and Ihantola 2018). The business partner seems also to be an attractive ideal among management accountants themselves, guiding their individual preferences and expectations (Järvenpää 2007; Cieslak 2011; Lepistö and Ihantola 2018).

On the other hand, previous research suggests that certain forces work in the opposite direction. Perhaps the most conspicuous of drivers pulling the management accountant from a straightforward business partner toward a hybrid role, thus blending business partnering with traditional accounting, is accounting regulation (Friedman and Lyne 1997; Byrne and Pierce 2007; De Loo et al. 2011). For example, it is difficult to envision how compliance with International Financial Reporting Standards (IFRS) or the Sarbanes-Oxley Act (SOX) can be ascertained from a pure business partner point of view. Relatedly, internal performance monitoring policies and guidelines (Coad 1996; Friedman and Lyne 1997), regularized tasks and responsibilities, and the presence of financial control systems (Yazdifar and Tsamenyi 2005) encourage a blended role for the management accountant rather than the business partner.

Previous research also reveals that norms and expectations can serve as drivers of a hybrid accountant role. The accounting profession relies on traditional accounting norms, including truth, fairness, and objectivity (Maas and Matejka 2009). Professional accounting norms may thus work in the opposite direction of cultural organizational norms, thereby supporting a hybrid accountant role. In addition, the prospect of management accountant involvement in decision-making can be viewed as threatening by operational managers who may prefer to lock the management accountants out, stopping them from acting as business partners (Lambert and Sponem 2012). Thus, it would seem that operational management expectations support a hybrid accounting role. Task variety and dual responsibilities also support a hybrid role among management accountants (Maas and Matejka 2009; Weber 2011; Rieg 2018). Evidence also suggests that the view and actions of the individual management accountant, possibly supported by his or her professional norms, can be a balancing factor in relation to business partner drivers. In this way, the hybrid accountant role can be driven by the attitude, personality, and initiative of the management accountant (Byrne and Pierce 2007). See Table 1 for an overview of business partner and hybrid accountant drivers identified in previous research.

Relating the overview presented in Table 1 to the research question addressed in this paper, the drivers of a hybrid accountant can be grouped in different categories. While some drivers rely on coercion and a regulative logic, others are based on norms or on the frames of reference of the individual management accountants. Little attention has been devoted to such categorization in previous research. This paper 


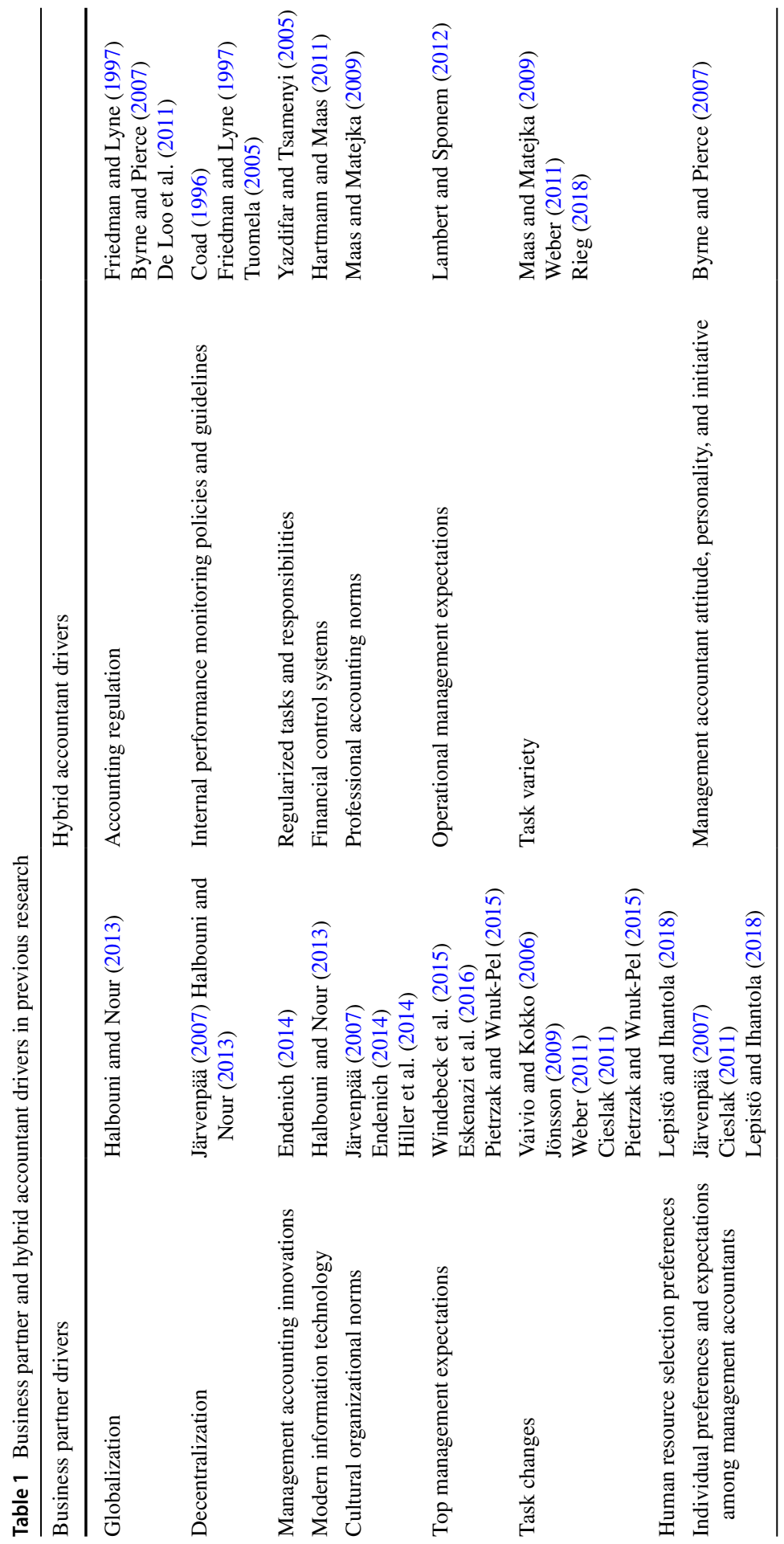


suggests that grouping hybrid accountant drivers into different categories makes it possible to reduce the level of detail, thereby bringing the analysis to a conceptual level. By exploring different categories of institutional drivers, it should be possible to understand the forces at play in a more nuanced way than if the drivers are treated as one homogeneous group.

According to institutional theory, the institutional drivers shaping roles in organizations possess regulative, normative, and cognitive dimensions (Scott 2013, p. 97). Therefore, we suggest that these dimensions should be considered when addressing the question of how it is possible to explain the prevalence of hybrid accountants in management accounting practice.

Palthe (2014) adapted Scott's (2013) framework to research regarding changes in management. The regulatory dimension emphasizes rule systems, "what the actors' roles have to be" (Palthe 2014). From this position, change is accomplished through symbolic legal systems, relational policies and rules, activities with a legal obligation, and artifacts containing coercive routines and protocols (Palthe 2014). Traditionally, accounting is associated with regulative institutional drivers reflecting how actors' roles are constrained and regularized. For example, accounting standards and regulations can help explain management accountant work with financial reporting, monitoring, and compliance (Friedman and Lyne 1997; Byrne and Pierce 2007).

Research on the role of management accountants is rich with role-like terms, such as "watchdog" (Granlund and Lukka 1997), "number cruncher" (Byrne and Pierce 2007), "corporate police" (Yazdifar and Tsamenyi 2005), and "bean counter" (Burns and Baldvinsdottir 2007). While these terms tend to be used with negative connotations, some research suggests that traditional management accountants are valued by other organizational actors for their financial accounting expertise (Burns and Baldvinsdottir 2007). Hence, in a business partner context, regulative institutional drivers may pull the management accountant in a traditional direction, thus leading to adoption of a hybrid accountant role.

The normative dimension stresses prescriptions for how actors should behave, "what the actors' role ought to be" (Scott 2013, p. 64). From this perspective, roles are shaped by a sense of social obligation (Palthe 2014). The normative dimension is supported by symbolic ethical systems, relational habits and work roles, activities promoting duty and responsibility, and artifacts sustaining moral responsibility (Palthe 2014). Normative institutional drivers constitute an important explanatory platform for the management accountant role (Järvenpää 2007). The normative institutional drivers behind the business partner role are often related to expectations of social and problem-solving skills, including the ability to interact, communicate, and analyze problems and the provision of support to subordinates, peers, and superiors (Hopper 1980; Hartmann and Maas 2011; Weber 2011).

However, existing norms do not necessarily contribute to the promotion of a business partner role. For example, the professional norms in the accounting field (e.g., "true and fair view") can have a contrasting impact of the role of the management accountant. Ethical guidelines may be designed to uphold traditional accounting values. Thus, in a business partner-oriented context, professional accounting norms can support the traditional side of accounting, thereby creating a hybrid accountant. However, the management accounting literature often equates the business 
partner with a normative ideal referred to as "internal consultant" (Mouritsen 1996), "change agent" (Granlund and Lukka 1997), "business-oriented role" (Burns and Baldvinsdottir 2005), or "co-pilot" (Lambert and Sponem 2012).

The cognitive dimension emphasizes a shared conception of a social reality (Palthe 2014), which is based on the actors' own aspirations and internal representations of the context, "what the actor wants her role to be" (Scott 2013, p. 67). This dimension is supported through symbolic cultural systems, relational beliefs and assumptions, activities of personal desire and moral responsibility, and artifacts carrying personal value, such as a pay raise or bigger office (Palthe 2014). Research indicates that the management accountant's own preferences substantially influence his or her role (Byrne and Pierce 2007). Because cognitive drivers are subjective and individual, they can be expected to facilitate a business partner role or a more traditional management accounting approach, depending on the actor's beliefs and assumptions (Vaivio 2008; Lepistö and Ihantola 2018).

\section{Methodology}

\subsection{An overall introduction to the case study company}

The case study organization is a Swedish high-tech international minerals group, which is a supplier of processed iron ore products for steelmaking and other mineral products. Similar to a study on management accountant roles in Germany (Goretzki et al. 2013), Swedish institutions provide a context in which management accountants are central actors in organizational financial flows. For this reason, they are distinct from other organizational groups of professional actors (Lindvall 2009, p. 62; Nilsson and Olve 2013, p. 20).

Appropriate contexts are important for interpretive case studies (Lukka 2014). The selected organization was considered appropriate for studying the management accountant role for three reasons. First, the case study organization was carrying out a change project pursued to transform its management accountants from a traditional to a business partner role. Second, the organization was the single largest industrial investor in Sweden; hence, it was large enough to provide access to several management accountants. Third, capital investment projects in the mining industry carry high uncertainty and risk, thus creating a challenging setting for project managers, top-level managers, and management accountants (PWC 2012). Because they manage vital financial information, accountants are important actors in such environments (Nilsson and Olve 2013, p. 60).

\subsection{Sources of empirical evidence and interpretations}

Interviews form the basis for the study, although documents and direct observations are included. The interviews were conducted during three field visits in March 2014, June 2015, and November 2015. Two semi-structured interview guides were used, allowing for discussions. The first interview guide aimed at understanding the 
management accountant role, the projects that the management accountants worked on, and their collaboration with other actors in the mining context. The second interview guide aimed at understanding how the management accountants constructed and used calculations for capital investment projects. The interview guides provided a way to keep our discussion during the interviews centered on the management accountants' everyday practice in this context. The first interview guide was used in the first field visit, and during the second and third field visits both interview guides were used and complemented each other in discussions with actors in the organization.

The interviewees included management accountants, project managers, and the chief financial officer (CFO), whose interview was not recorded. Actors to include in the interviews were determined by requesting the participation of management accountants and actors involved in management accounting work and with insights into the management accountant role. The interviews lasted for a total of $20 \mathrm{~h}$ with 15 actors interviewed. The interviews were recorded and transcribed.

The documents collected in this study included flow charts and facts concerning internal guidelines, educational material, role descriptions, templates, and organizational charts. The study also provided the opportunity to partake in meetings with company officials. In addition, the researchers attended a meeting with the group finance staff for a presentation of their strategic objectives and organizational structure. They also participated in a workshop with the head of the controlling department to discuss preliminary findings and deepen the understanding of the internal views on policies and procedures associated with the management accountant role (see "Appendix 1" for a description of the data sources).

The transcribed interviews were interpreted in relation to the referenced research question of how it is possible, despite the persuasive characteristics of the business partner role, to explain the prevalence of hybrid accountants in a management accounting practice. Also, to identify what impedes or facilitates a management accountant's role, institutional regulative (have to), normative (ought to), and cognitive (want to) drivers were used to interpret the empirical data (c.f. Scott 2013, pp. 60-67). We aimed to identify the drivers of a hybrid accountant role in a business partner-oriented context. Thus, we defined those drivers as forces supporting traditional management accounting in a setting where the business partner ideal is sought. The intention was to enable theoretically informed assessments of episodes and quotations from the interviews that highlight management accountant role change, management accounting work, and how the actors themselves viewed the role of the management accountant. The interpretations in our concluding discussion were built on the theoretically identified drivers of a hybrid accountant role, but also on other patterns we found in our empirical data. We used a coding scheme to identify instances of regulative, normative, and cognitive institutional drivers in the empirical data that shaped the management accountant role ("Appendix 2").

Under an interpretive approach, reliability rests on establishing that the actors being studied say valid things about the phenomena in question (Ahrens and Chapman 2006). Reliability can also be addressed by letting peers assess the interpretations of data. The interpretations were initially made by the first author. The coauthors then independently coded randomly chosen interview transcripts. Their 
coding was then compared with the interpretations made by the first author. Differences in how the authors interpreted the interview transcripts were few and could be resolved by discussing them in light of the coding scheme to reach a consensus.

\section{Case study: the role of management accountants in a mining company and its institutional drivers}

\subsection{The management accounting function in the case company}

At the time of our study, the case company had 24 management accountants working directly subordinate to the chief executive officer (CEO). A separate financial accounting department was responsible for the recording of accounting transactions. The management accountants' overall function was to support the operational areas of the organization, management, the $\mathrm{CEO}$, and the board of directors.

Being a management accountant in the mining industry means making a variety of large and complex investments; hence, considerable variety exists in the work in practice. At the time of our study, the management accountants worked with different types of investment projects ranging from investments in new mining levels to investments in processing facilities, transportation, and shipping. The case company had not previously made these kinds of large and complex investments. Therefore, the management accountants had no previous examples to follow.

\subsection{Regulative drivers of the management accountant role}

The case company's internal guidelines stated three main areas of responsibility for management accountants working with capital investment projects: (1) monitoring and follow-up of budgets and outcomes, (2) monitoring the progress of the investment plan, and (3) providing financial information to project managers, project leaders, top-level managers, and the board of directors. The management accountants also worked with administration to develop processes to safeguard good internal compliance, governance, risk management, and control. The company guidelines show that management accountants were present in all stages of a capital investment process and, depending on the type of investment, the tasks of the management accountants and others' expectations of them varied.

During the time of our study, the company had initiated a change program with the aim of transforming its management accountants into business partners. This change was stated as a goal for the management accountant function in the business plan. The corporate view of how to accomplish this transformation was included in a document called Road map toward becoming a business partner. The road map included a drawing of a staircase, depicting the tasks that the company considered to belong to the business partner role (see Fig. 1).

According to the road map, the organization separated accounting work from other tasks of the management accountant. In the company's view, the reporting, analysis, and strategy areas should all be related to the business partner role, while 
Fig. 1 Progression of management accountants toward business partners in the mining company

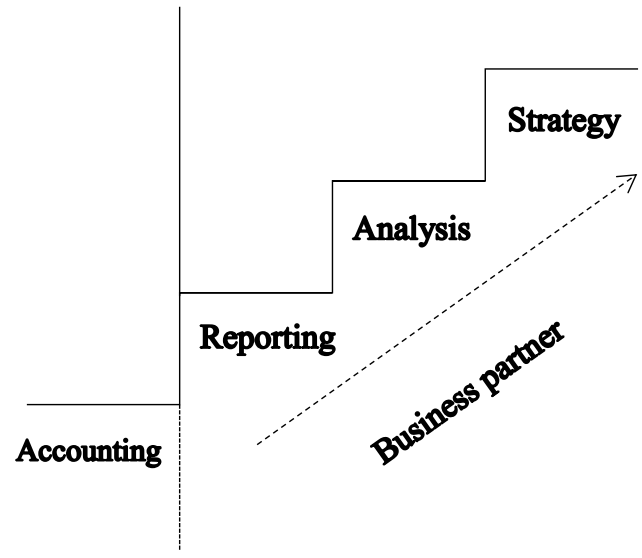

accounting work was considered part of the traditional management accountant's role. Capital investment management accountant (A) described the accounting tasks represented in the staircase in the following way:

This step entails the basic bookkeeping, which entails keeping a current recording of business transactions and coding expenses to the right accounts. We have a separate accounting department to assist with bookkeeping matters. All production managers and section managers are also required to carry out basic budgeting tasks. The goal is that the management accountants should leave such routine matters although we sometimes are involved as well.

Management accountant work in practice meant that the management accountant was involved in the management process of different types of mining investment projects. Such projects ranged from mining for ore extraction, underground logistics, concentration plants, and pelletizing plants to logistics for shipping to the global market. When capital investment management accountant (A) from mining division south explained his view on the management accountant role, he related his explanation to the management accountant role areas presented in Fig. 1:

The reporting step is traditional management accountant work of reporting, monitoring, and following up on historical budgets. On the analytical step, we have more qualified work that involves analytically trying out scenarios. The strategy step is even more analytical work.

The quotation above indicates that the management accountant saw reporting as a more traditional task, while analysis and strategy work were perceived as more qualified work. Here, the management accountant said that more qualified management accountant work demanded management accountants who would try out different scenarios and conduct what-if analyses. The most frequent task management accountants mentioned was the provision of financial information to project managers, top management, and the board of directors.

The management accountants explained that when the new board of directors was installed the directors demanded more than traditional management accounting 
work from the management accountants. The management accountant in charge of financial projections for new main levels explained:

Top management has explicitly stated that we management accountants need to include strategic scenarios in our financial reports. We have to reflect over and discuss alternatives in the financial reports because that is what management considers quality and value.

Thus, the new top management expected the management accountants to work in a strategic and forward-looking manner. The management accountants, project managers, and top management all said that the management accountants had to understand the mining operations. The group CFO explained this in the following way:

The management accountant must also gain an understanding of the operational activities. Many management accountants trust too much in guidelines. Top management wants to know what is real and the management accountants need to be a part of a team.

The quotation above indicates that management accountants working with capital investment projects were expected to have competence in areas other than financial accounting. This type of competence allowed the management accountants to communicate with operating managers, which enabled them to produce relevant financial information to the board of directors.

In sum, the results suggest that the regulative drivers of the role of the management accountant included internal regulations and guidelines that emphasized traditional management accountant work. These instructions ran counter to the corporate business partner change program, including requirements from the board and top management and the new business partner role description (Table 1).

\subsection{Normative drivers of the management accountant role}

Investment management accountant (C) from mining division north, who had considerable experience working within the organization, explained more about management accountant work in practice:

Within these large-scale mining investments, we management accountants support other managers with calculations and cost estimations. Much of what we do depends on the size of the investment projects. The really big investments, those costing billions, require us management accountants to be really involved as a part of the teams in charge of the investments. For smaller investments, we are basically reporters and creators of accounting information.

This statement indicates that the size of investment projects mattered. Apparently, management accountants needed to work more strategically, and business partnering became a more important aspect of management accountant practice when investment projects were larger in monetary terms and in capital intensity. The project manager from division south elaborated on the importance of management accountant assistance during large-scale investments: 
The mining project costs are significant. If I just try to put it into perspective, then for a single new mining truck the costs are around 400,000 euros. A new mining level could cost from 1 billion euros or more. We need management accountants because they help us see that these costs are, in the end, necessary for maintaining profitability.

In this quotation, the project manager credits management accountants as being valuable and important actors, thus providing an overview of the investment projects by compiling significant investment costs. The project manager from division south provided his view on management accountant practice:

We are engineers who operate in the largest and most technically advanced underground iron ore mining operation in the world. Our job is technical and we provide cost estimations and feasibility reports of existing and new investments. But the management accountants do the accounting work involving interest, calculations, and financial predictions, while we provide the tangible costs that they can work with.

The project managers confirmed that they wanted the management accountants to perform accounting tasks which were not closely related to business partnering. The following quotation from investment management accountant (A) provides another example of why traditional accounting work remained part of management accountant practice:

The head of the management accountant department wants us management accountants to free up our time so that we can do more analytical strategic work. Therefore, the management accountant department produced a handbook, which the project managers can use as a guide and make their own basic accounting work. However, we still have to do this for them; the other managers do not want this extra work. They believe it is hard work and maybe they are a little afraid that they'll make mistakes as well.

This quotation illustrates that accounting work can be seen as daunting for the engineering-focused project managers, leaving the management accountants no choice but to perform such accounting work themselves. The experienced capital investment management accountant (B) from mining division north explained this a bit further:

The new board of directors asked new types of questions. We could no longer just report financial information; the demand for more explanatory management accounting increased. This meant that we had to write more extensive memorandums to the board of directors, which included operational activities and forecasts.

Top management also wanted the management accountants to visit the different mining sites to observe the mining operations with their own eyes. The financial management accountant explained this in greater detail: 
We were supposed to do a progress report to the board of directors. However, the mining site was so far from the company headquarters that they wanted us to visit the mining site. In doing so, we management accountants learned from the operational work and got to talk with operational actors. By doing this, we could communicate a sense of the real world to the board and this was appreciated by them. For us, it related to a supportive relationship to both operational and top-level management.

This above quotation indicates that top management wanted the management accountants to do more analysis and strategy work, while the operations managers wanted them to work in a more traditional way (i.e., reporting financial facts in different types of reports). Top management also wanted the management accountants to present information other than financial reports. Top management requested oral communication and direct observations from the management accountants.

As earlier indicated, the operations managers wanted the management accountants to work in a traditional manner. They valued the management accountants' financial expertise and wanted them to present financial facts in formal management reports. Capital investment management accountant $(F)$ from mining division north provided two possible explanations for this view among the operations managers:

The operational actors mostly want us simply to do financial calculations. The operational actors might actually feel threatened and want management accountants to handle the compilation of financial information. The reason for this is that simpler financial work, budgets, and just compiling numbers is something that they can do themselves but they do not want more work. They also feel that we might infringe on their territory and by learning about operations gain more power through influence. It is a balancing act.

This example suggests that operational actors had concerns that the management accountants should remain in their financial domain, thereby not infringing on their operational areas. The project manager in charge of feasibility studies and planning new mining levels provided another example of this line of reasoning:

I can do a lot of financial work myself, and I have done it. However, mostly the project managers need the management accountants to help them with financial numbers because they are the experts of such matters and we are experts at our specific operational areas. However, we both need to understand each other and that is why we need to meet and discuss such matters.

This indicates that operational actors thought that management accountants should work in a traditional manner. The management accountants said that they lived in a fast-changing world and needed to keep up with new information technology and styles. New information technology could help the management accountants customize the accounting information according to need. In the words of capital investment management accountant $(\mathrm{C})$ from mining division south:

Payoff and return-on-investment calculations are easy; we management accountants want to automate such activities. Finding the right informa- 
tion and then presenting these calculations to other actors is the hard part. A business partner role means that we management accountants have to investigate, question, and also discuss these matters with other actors in the organization.

This quotation illustrates that the management accountants themselves welcomed new information technology (IT) and found it valuable because it could help them tailor the accounting information to the users. Capital investment management accountant (B) explained what newly implemented information technology meant to the management accountants:

For us management accountants, the new accounting systems called Movex meant more people to interact with, where we management accountants have to administer so that everyone understands the system. We management accountants coordinated other actors, consultants, project managers for how they should interact and use the accounting system. It was a massive project in itself; it took several years to get everyone on board. Nevertheless, we have to adapt; the world around us changes, and we have to keep up.

This quotation illustrates that even a large organization like the case organization had to keep up with globalization. Moreover, IT systems and globalization seemed to be triggers for business partnering among management accountants, driving them toward more interaction with other actors. Capital investment management accountant (E) from mining division north elaborated on the implementation of new information technology, which involved more people:

Many times, the operational actors are highly educated specialists. They can do the calculations by themselves, but they might not have time to reflect upon them and do them properly. It is part of our role to ponder and reflect upon calculations. New IT means that we have to help other actors to use the systems because they still need to focus on their main areas of expertise. That makes us management accountants an asset.

New information technology supported a business partner role in several ways. New IT systems allowed access by users from fields of expertise other than the financial and management accounting fields, wherein the management accountants are the experts. This created a demand for guidance among the users for how they were supposed to work with such systems, guidance that the management accountants provided. Capital investment management accountant (C) from division south also highlighted the importance of gaining an understanding of the operational activities to create relevant financial reports and analysis. He described it in the following way:

Instead of sitting in our office doing pay-off calculations for a new pelletizing plant, we go and visit the site and discuss the investment with the operational managers. This increases our technical awareness of how things are connected in the larger scheme, which has two advantages. First, it increases 
our business insights when doing calculations because a pelletizing plant is only one part in the entire value chain. Second, knowing the technical reality helps us to gain the operational manager's trust, which is important for us management accountants. Trust eases the flow of financial information between operational actors and us management accountants.

This quotation also suggests that because of the visits, the management accountants could present more relevant financial information and conduct better analyses than if the management accountants had based their information only on financial facts. However, the project manager at division south stressed that:

As project managers we have an allocated budget that we are in charge of and held responsible for. There are so many ways that management accountants can present facts and information to us. To uphold our obligations is challenging and we need hard facts and numbers, even though they may be less informative sometimes. Accordingly, we demand accounting information presented in a spreadsheets format from our management accountants.

The quotation above implies ambiguities regarding the management accountant's role. The management accountants seemed to need a business partnering role to obtain important qualitative information from operations. However, the project managers pushed back by requesting traditional accounting work from them.

To summarize, the results suggest a number of normative drivers of the management accountant role, some of which appear to work in opposite directions. Task changes occurring as a result of the capital investment program, operations manager expectations concerning advisory management accounting contributions to large-scale capital investment projects, and expectations for basic accounting work being conducted by the operations managers themselves worked in favor of a business partner role for the management accountants. Through the possibilities to tailor the accounting information, the needs for interaction with operations managers, and their need for management accountant guidance, modern information technology has influenced development of the management accountant role in the same direction. The same goes for the cultural norm in the organization that stipulated the necessity for management accountants to understand business operations. In contrast, operations managers appeared to expect traditional management accountant functions and expressed a reluctance to take on basic accounting tasks themselves.

\subsection{Cognitive drivers of the management accountant role}

When asked how a management accountant becomes a business partner, capital investment management accountant $(\mathrm{G})$ from mining division south explained:

I want to work more with operational actors and learn operations. This is how I get to do work that is more qualified and get more influence in our line of work. A business-oriented role is an interesting challenge where we have to be able to adapt to situations. It allows more freedom and reflective 
interpretations where we do not have to be so constrained by budgets and financial reports.

The quotation above indicates that the management accountants themselves regarded business partnering as something to strive for, and they considered a business partner role to involve more influencing and partaking in decision-making processes. The company guidelines provided a framework for the management accountants, promoted the business partner role, highlighted the responsibility areas, and stated what tasks the management accountants should undertake in investment projects. However, when interviewing the $\mathrm{CFO}$, the project managers, and the management accountants themselves, they had expectations and views on the management accountants' role in the case company that differed from those presented in the formal documents. The interview with capital investment management accountant (D) from mining division north provided an illustration of why the management accountants found it difficult to climb the steps, as presented in Fig. 1:

We management accountants are an asset because we deliver financial reports to project managers, who are experts in their own right. They know how to do basic calculations which make up financial reports, so in a way by keeping the rather rational accounting tasks among our management accountant group we show them that we management accountants are necessary in the organization and that we deliver something tangible to them. Keeping such accounting tasks also lends a certain influence because we are the owners of the material that we produce.

The quotation above is interesting because it contradicts what capital investment management accountant $(\mathrm{G})$ previously said about business partnering being key to influence. Here, the management accountant instead suggested that the management accountants wanted to uphold traditional accounting work because otherwise they would forgo influence within the organization by losing instrumental control. The results show that knowledge of operations also meant more power in decision-making. As capital investment management accountant (D) from mining division north explained:

We management accountants are seldom questioned during our discussions with management. If we present several investment proposals and argue for one particular option, our know-how and expertise is not something management questions. We usually get our way.

This could be one explanation for why the management accountants wanted to be business partners, as it apparently gave them more influence in discussions with management. Capital investment management accountant (A) from mining division south stated:

I want to speak with operational actors and see them face-to-face; actually, interpreting and reading body language helps in determining the quality in financial information. I value sitting down with operational actors over cof- 
fee and just listening in on conversations. Obtaining financial information is a bit like detective work because sometimes what is not said can be the most important area to focus on.

The above quotation implies that to strengthen the quality of accounting information the management accountants had to be versed in mining operational areas.

In sum, the results also reveal cognitive drivers of the management accountant role that seem to counteract each other. The prospects of acquiring greater autonomy and influence on operations, especially when it comes to large-scale capital investment projects, motivated management accountants to strive for a business partner role. On the other hand, some favored traditional accounting work because they associated it with a management accountant impact on smaller investment projects through the consolidation of core accounting tasks among the management accountants.

\subsection{Facilitating and impeding institutional drivers in the mining company}

The results show facilitating regulative business partner drivers in the form of board and top management requirements and the existence of a formal business partner role description. The facilitating impact of regulative institutional drivers supports Pietrzak and Wnuk-Pel (2015) and Windebeck et al. (2015), who found internal regulating factors behind the role change among management accountants. In contrast, the results also indicate that internal management accounting policies and guidelines are important regulative drivers that can impede the transition of management accountants into a business partner role. This finding is in line with Coad (1996), who related the programming of accounting work to a traditional role, and Friedman and Lyne (1997), who found support for the relationship between guidelines and broadening of the management accountant role. In addition to the corroboration of previous research findings, the empirical evidence presented here suggests the coexistence of regulative institutional drivers that both impede and facilitate the business partner role.

The results also reveal normative drivers that facilitate and impede the business partner role. Top management expectations play a facilitating role in relation to business partnering. Also, operational management expectations concerning interaction and guidance work in favor of the management accountant as business partner. Previous research has reached similar conclusions, finding social pressure from management to be a motivator behind the adoption of a new role among management accountants (Eskenazi et al. 2016). In addition, this study indicates that modern information technology constitutes a facilitating normative driver of the business partner role. As Halbouni and Nour (2013) suggest, modern information technology allows management accountants a different role through a broader spectrum of management information and greater interaction with operations.

This study offers evidence of two normative institutional drivers that impede the transition of management accountants into business partners. First, cultural organizational norms (in this case associated with the nature of the engineering and accounting professions) may be such that they encourage traditional 
accounting work among management accountants. In contrast, cultural organizational norms can facilitate a business partner role through recruitment or career planning (Järvenpää 2007), as a response to organizational crises (Endenich 2014), or by attributing increased prestige to the business partner role (Hiller et al. 2014). Second, operational management expectations concerning scorekeeping can hamper the business partner role. Lambert and Sponem (2012) also report that operational managers may hinder the evolution of the business partner role, arguing that it jeopardizes their autonomy. In any case, different operational management expectations influence the management accountant role in different ways, thereby potentially causing tensions.

Finally, the results suggest that individual preferences and expectations among management accountants constitute both impeding and facilitating cognitive drivers of a business partner role. This finding corroborates the results of Lepistö and Ihantolo (2018), suggesting that the management accountant role is associated with the personal qualities of the accountants themselves. In addition, the results reported here show that while some management accountants prefer the autonomy and influence associated with a business partner role, others favor the core competencies of a traditional role. Thus, the results indicate different views as to what management accountants want their own role to be.

\section{Conclusions, limitations, and suggestions for future research}

This paper addresses the question of how it is possible, despite the persuasive characteristics of the business partner role, to explain the prevalence of hybrid accountants in management accounting practice. The question is addressed by exploring the institutional drivers facilitating and impeding the business partner role in a mining company wherein the management accountant role is subject to a program effort aiming to turn management accountants into business partners. Below, we present the conclusions of the study, its limitations, and suggestions for future research.

\subsection{Hybrid accountants in the age of the business partner}

This paper illustrates how a hybrid accountant role comes into existence in the context of tension where the management accountants are required to balance between institutional drivers that operate in opposite directions, some of which favor the business-oriented management accountant and others that support traditional accounting work. Thus, the persuasive characteristics of the business partner ideal and its facilitating institutional drivers are not sufficient to entirely counteract the forces that work in a traditional management accounting direction. Using Scott's (2013) institutional pillar framework and its adaptation to change management by Palthe (2014), we show that the institutional drivers involved in this dynamic interchange are regulative and normative, as well as cognitive. 


\subsection{Institutional drivers facilitating and impeding the business partner ideal}

We conclude that board and top management requirements along with the existence of a formal business partner role description at the organizational level can serve as regulative institutional drivers that facilitate the transition of the management accountant toward a business partner role. On the other hand, internal management accounting policies and guidelines can work in the opposite direction, as regulative institutional drivers that impede business partnering, by emphasizing traditional accounting responsibilities and procedures.

We also find that top management expectations, operational management expectations concerning interaction and guidance, and modern information technology can function as normative drivers that explain what the management accountants ought to do, thereby facilitating the business partner ideal. Our study also illustrates how cultural organizational norms and operational management expectations concerning scorekeeping can contrast with the facilitators, thereby serving an impeding function.

Cognitive drivers may also influence the role of the management accountant in different ways. The case study reported here shows that the individual preferences and expectations among the management accountants themselves can differ. We find that some individual preferences and expectations facilitate the business partner by emphasizing autonomy and influence, but others impede the very same development by stressing the core competence of management accountants.

Although the specific institutional drivers and the extent to which they facilitate or impede may vary in any given case, their interplay is an important explanation for the characteristics of the management accountant role in practice. See Table 2 for a summary of the different drivers identified in this study.

The different institutional drivers shaping the management accountant role in the study reported here have largely been identified as single driving forces in previous research efforts. However, building on previous studies, this paper provides insights into how multiple institutional drivers can simultaneously have a facilitating and impeding function, thereby potentially contributing to tension and to a broader hybrid accountant role with traits of business partnering and traditional accounting.

\subsection{Limitations and suggestions for future research}

The results and conclusions presented here are based on a single case study. The validity of the explanation provided in this paper with respect to the prevalence of hybrid accountants can be strengthened by subjecting it to a broader empirical examination. The institutional driver framework (Table 2) can be tested in a statistical survey. More encompassing in-depth data collection in a single case study can also be helpful in identifying additional institutional drivers and tensions beyond those presented in Table 2. This type of research can also be oriented 
Table 2 Institutional drivers facilitating and impeding the business partner ideal

\begin{tabular}{lll}
\hline Institutional drivers & Facilitating & Impeding \\
\hline Regulative (have to) & $\begin{array}{l}\text { Board and top management requirements } \\
\text { Business partner role description }\end{array}$ & $\begin{array}{c}\text { Internal management accounting } \\
\text { policies and guidelines }\end{array}$ \\
Normative (ought to) & $\begin{array}{c}\text { Top management expectations } \\
\text { Operational management expectations } \\
\text { concerning interaction and guidance }\end{array}$ & $\begin{array}{c}\text { Operational management expecta- } \\
\text { tions concerning scorekeeping }\end{array}$ \\
& $\begin{array}{l}\text { Modern information technology } \\
\text { Individual preferences and expectations } \\
\text { among management accountants con- }\end{array}$ & $\begin{array}{c}\text { Individual preferences and } \\
\text { expectations among management } \\
\text { cognitive (want to) }\end{array}$ \\
& $\begin{array}{c}\text { cerning autonomy and influence } \\
\text { competencies }\end{array}$ \\
\hline
\end{tabular}

toward untangling the ways in which different institutional drivers are linked to each other. For example, one can hypothesize that normative top management expectations result in regulative policies that, eventually, alter the individual preferences and expectations among management accountants themselves. In particular, we suggest that shadowing represents an interesting research approach to consider in future work on institutional drivers of the management accountant role.

Theoretically, this paper is informed by Scott (2013) and by the Palthe (2014) framework as a lens to explain the drivers behind the hybrid accountant role in practice. Alternatively, it would be interesting to use practice-driven institutionalism (Smets et al. 2017) in future research on the everyday practices of (management) accountants.

Open Access This article is distributed under the terms of the Creative Commons Attribution 4.0 International License (http://creativecommons.org/licenses/by/4.0/), which permits unrestricted use, distribution, and reproduction in any medium, provided you give appropriate credit to the original author(s) and the source, provide a link to the Creative Commons license, and indicate if changes were made.

\section{Appendix 1}

See Table 3. 
Table 3 Overview of fieldwork data sources

Interview round one \#

Capital investment management accountants (A, B, C, D) 4

$\begin{array}{ll}\text { Chief financial officer (not recorded) } & 1\end{array}$

Project manager: division south 1

Interview round two

Management accountant: financial projections for new main level 1

Capital investment management accountant (A) 1

Project manager: feasibility studies and planning of new main levels $\quad 1$

Interview round three

Capital investment management accountants (A, E, F, G) 4

Financial management accountant $\quad 1$

Project manager: division north $\quad 1$

Documents

Research diary and field notes

ongoing

Flow charts and time plan for strategic capital investment projects (SCIPs) 1

Internal guideline documents $\quad 1$

Management control process $\quad 1$

$\begin{array}{ll}\text { Capital investment process } & 1\end{array}$

Introductory accounting and control procedures $\quad 1$

Management accountant role and work descriptions $\quad 1$

Template for the presentation of capital investment proposals to the board 2

Organizational chart, management accountant group 1

Documentation of ongoing SCIPs 1

Memorandum intended for the board of directors preceding investment decision 1

Document showing number of SCIPs handled by one capital investment management account- 1 ant

Observations and attendance at meetings

Participation in company learning programs (sessions) 3

Workshop presentation 1

Presentation at company headquarters $\quad 1$

$\begin{array}{ll}\text { Various on-site meetings (days) } & 7\end{array}$

\section{Appendix 2}

See Table 4. 


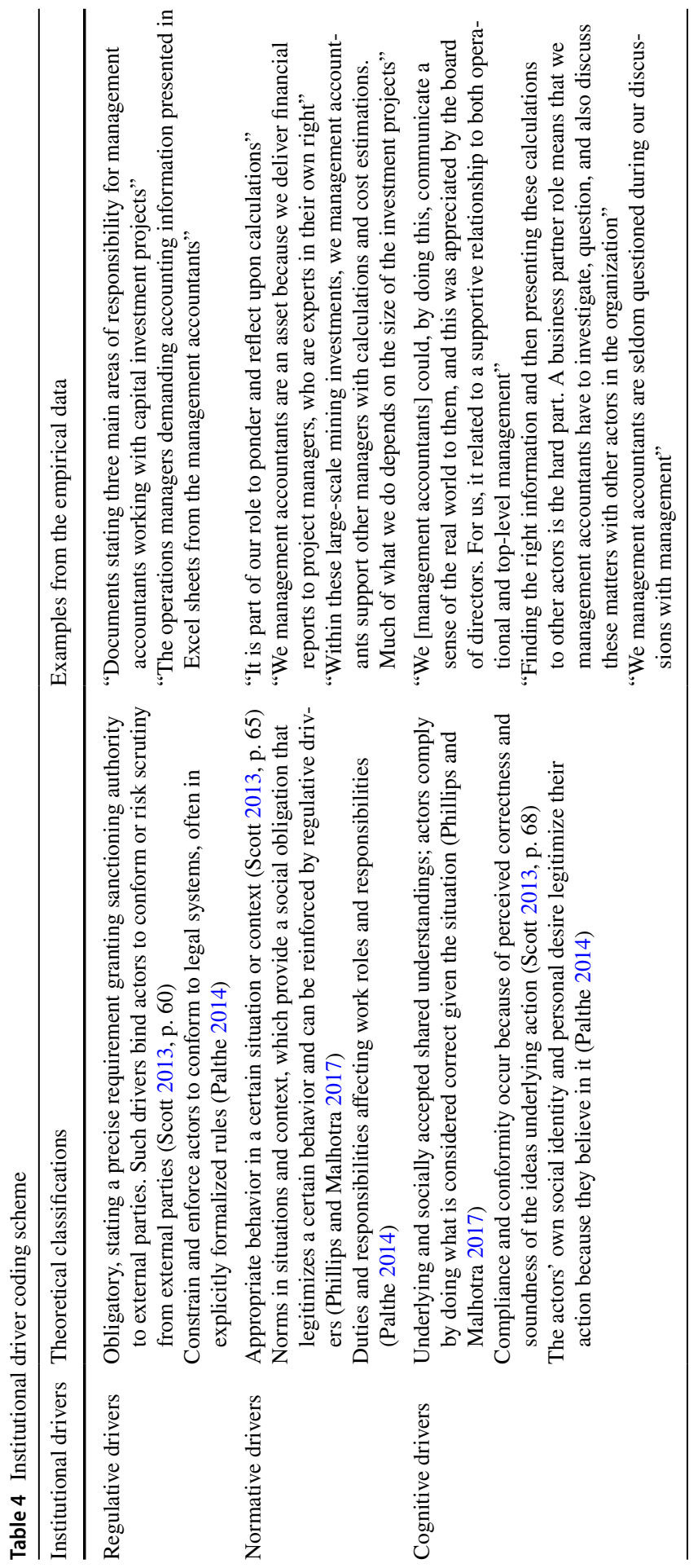




\section{References}

Ahrens, T., \& Chapman, C. S. (2006). Doing qualitative field research in management accounting: Positioning data to contribute to theory. Accounting, Organizations and Society, 31(8), 819-841.

Baldvinsdottir, G., Burns, J., Nørreklit, H., \& Scapens, R. W. (2009). The image of accountants: From bean counters to extreme accountants. Accounting, Auditing \& Accountability Journal, 22(6), 858-882.

Barley, S. R., \& Tolbert, P. S. (1997). Institutionalization and structuration: Studying the links between action and institution. Organization Studies, 18(1), 93-117.

Battilana, J., Besharov, M., \& Mitzinneck, B. (2017). On hybrids and hybrid organizing: A review and roadmap for future research. In R. Greenwood, C. Oliver, T. B. Lawrence, \& R. Meyer (Eds.), The SAGE handbook of organizational institutionalism (Vol. 2, pp. 133-169). Thousand Oaks: SAGE.

Baxter, J., \& Chua, W. F. (2009). Studying accounting in action: The challenge of engaging with management accounting practice. In Accounting, organizations, and institutions, pp. 65-84.

Bhappu, R. R., \& Guzman, J. (1995). Mineral investment decision making. Engineering and Mining Journal, 7, 36-38.

Broadbent, J., \& Laughlin, R. (2009). Performance management systems: A conceptual model. Management Accounting Research, 20(4), 283-295.

Burns, J., \& Baldvinsdottir, G. (2005). An institutional perspective of accountants' new roles-The interplay of contradictions and praxis. European Accounting Review, 14(4), 725-757.

Burns, J., \& Baldvinsdottir, G. (2007). The changing role of management accountants. Issues in Management Accounting, 3, 117-132.

Burns, J., \& Scapens, R. W. (2000). Conceptualizing management accounting change: An institutional framework. Management Accounting Research, 11(1), 3-25.

Burns, J., \& Vaivio, J. (2001). Management accounting change. Management Accounting Research, 12(4), 389-402.

Byrne, S., \& Pierce, B. (2007). Towards a more comprehensive understanding of the roles of management accountants. European Accounting Review, 16(3), 469-498.

Chenhall, R. H., \& Moers, F. (2015). The role of innovation in the evolution of management accounting and its integration into management control. Accounting, Organizations and Society, 47, 1-13.

Cieslak, K. (2011). The work of the accounting and controlling department and its drivers: Understanding the concept of a business partner. Dissertation No. 122 Lund Studies in Economics and Management, Lund University.

Coad, A. (1996). Smart work and hard work: Explicating a learning orientation in strategic management accounting. Management Accounting Research, 7(4), 387-408.

De Loo, I., Verstegen, B., \& Swagerman, D. (2011). Understanding the roles of management accountants. European Business Review, 23(3), 287-313.

DiMaggio, P., \& Powell, W. W. (1983). The iron cage revisited: Collective rationality and institutional isomorphism in organizational fields. American Sociological Review, 48(2), 147-160.

Emsley, D. (2005). Restructuring the management accounting function: A note on the effect of role involvement on innovativeness. Management Accounting Research, 16(2), 157-177.

Endenich, C. (2014). Economic crisis as a driver of management accounting change: Comparative evidence from Germany and Spain. Journal of Applied Accounting Research, 15(1), 123-149.

Eskenazi, P. I., Hartmannn, F. G., \& Rietdijk, W. J. (2016). Why controllers compromise on their fiduciary duties: EEG evidence on the role of the human mirror neuron system. Accounting, Organizations and Society, 50, 41-50.

Friedman, A., \& Lyne, S. (1997). Activity-based techniques and the death of the bean counter. European Accounting Review, 6, 19-44.

Goretzki, L. (2013). Management accounting and the construction of the legitimate manager. Journal of Management Control, 23(4), 319-344.

Goretzki, L., Lukka, K., \& Messner, M. (2018). Controllers' use of informational tactics. Accounting and Business Research, 48(6), 700-726.

Goretzki, L., Strauss, E., \& Weber, J. (2013). An institutional perspective on the changes in management accountants' professional role. Management Accounting Research, 24(1), 41-63.

Graham, A., Davey-Evans, S., \& Toon, I. (2012). The developing role of the financial controller: Evidence from the UK. Journal of Applied Accounting Research, 13(1), 71-88. 
Granlund, M., \& Lukka, K. (1997). From bean-counters to change agents: The Finnish management accounting culture in transition. LTA, 3, 97.

Granlund, M., \& Lukka, K. (1998). Towards increasing business orientation: Finnish management accountants in a changing cultural context. Management Accounting Research, 9(2), 185-211.

Halbouni, S. S., \& Nour, M. A. (2013). An empirical investigation of the impact of globalisation and information technology on the role of the management accountant: Evidence from the United Arab Emirates. International Journal of Accounting, Auditing and Performance Evaluation, 9(3), 286-306.

Hartmann, F. G., \& Maas, V. S. (2011). The effects of uncertainty on the roles of controllers and budgets: An exploratory study. Accounting and Business Research, 41(5), 439-458.

Hiller, K., Mahlendorf, M. D., \& Weber, J. (2014). Management accountants' occupational prestige within the company: A social identity theory perspective. European Accounting Review, 23(4), 671-691.

Hopper, T. M. (1980). Role conflicts of management accountants and their position within organisation structures. Accounting, Organizations and Society, 5(4), 401-411.

Hyvönen, T., Jarvinen, J., \& Pellinen, J. (2015). Dynamics of creating a new role for business controllers. Finnish Journal of Business Economics, 64(1), 21-39.

Järvenpää, M. (2007). Making business partners: A case study on how management accounting culture was changed. European Accounting Review, 16(1), 99-142.

Järvenpää, M. (2009). The institutional pillars of management accounting function. Journal of Accounting \& Organizational Change, 5(4), 444-471.

Jönsson, S. (2009). The study of controller agency. In Accounting, organizations and institutions: Essay in honour of Anthony Hopwood.

Lambert, C., \& Sponem, S. (2012). Roles, authority and involvement of the management accounting function: A multiple case-study perspective. European Accounting Review, 21(3), 565-589.

Lepistö, L., \& Ihantola, E. M. (2018). Understanding the recruitment and selection processes of management accountants: An explorative study. Qualitative Research in Accounting \& Management, 15(1), 104-123.

Lindvall, J. (2009). Controllerns nya roll: Om verksamhetsstyrning i informationsrik miljö. Stockholm: Nordstedts akademiska förlag.

Linsley, P., \& Linsley, A. (2014). Cultural theory of risk and the notion of "management accountants as strategists". In Management control and uncertainty, Palgrave Macmillan, Basingstoke, pp. 224-238.

Lukka, K. (2014). Exploring the possibilities for causal explanation in interpretive research. Accounting, Organizations and Society, 39(7), 559-566.

Maas, V. S., \& Matejka, M. (2009). Balancing the dual responsibilities of business unit controllers: Field and survey evidence. Accounting Review, 84(4), 1233-1253.

Mouritsen, J. (1996). Five aspects of accounting departments' work. Management Accounting Research, 7(3), 283-303.

Nilsson, F., \& Olve, N. G. (2013). Controllerhandboken (10th ed.). Stockholm: Liber.

Palthe, J. (2014). Regulative, normative, and cognitive elements of organizations: Implications for managing change. Management and Organizational Studies, 1(2), 59.

Phillips, N., \& Malhotra, N. (2017). Language, cognition and institutions: Studying institutionalization using linguistic methods. In R. Greenwood, C. Oliver, T. B. Lawrence, \& R. Meyer (Eds.), The SAGE handbook of organizational institutionalism (Vol. 15, pp. 392-417). Thousand Oaks: SAGE.

Pietrzak, Ż., \& Wnuk-Pel, T. (2015). The roles and qualities of management accountants in organizations-Evidence from the field. Procedia-Social and Behavioral Sciences, 213, 281-285.

PWC. (2012). Mine 2012: The growing disconnects. Review of global trends in the mining industry. London: PWC.

Rieg, R. (2018). Tasks, interaction and role perception of management accountants: Evidence from Germany. Journal of Management Control, 1, 1-38.

Scott, W. R. (2013). Institutions and organizations: Ideas, interests, and identities (4th ed.). Thousand Oaks, CA: Publications Inc.

Smets, M., Aristidou, A., \& Whittington, R. (2017). Towards a practice-driven institutionalism. In R. Greenwood, C. Oliver, T. B. Lawrence, \& R. Meyer (Eds.), The SAGE handbook of organizational institutionalism (Vol. 14, pp. 365-391). Thousand Oaks: SAGE.

Tessier, S. (2014). Managing management controls. In Management control and uncertainty, Palgrave Macmillan, Basingstoke, pp. 149-161. 
Tuomela, T. S. (2005). The interplay of different levers of control: A case study of introducing a new performance measurement system. Management Accounting Research, 16(3), 293-320.

Vaivio, J. (2008). Qualitative management accounting research: Rationale, pitfalls and potential. Qualitative Research in Accounting \& Management, 5(1), 64-86.

Vaivio, J., \& Kokko, T. (2006). Counting big: Re-examining the concept of the bean counter controller. Liiketaloudellinen aikakauskirja, 55(1), 49-74.

Weber, J. (2011). The development of controller tasks: Explaining the nature of controllership and its changes. Journal of Management Control, 22(1), 25-46.

Windeck, D., Weber, J., \& Strauss, E. (2015). Enrolling managers to accept the business partner: The role of boundary objects. Journal of Management and Governance, 19(3), 617-653.

Yazdifar, H., \& Tsamenyi, M. (2005). Management accounting change and the changing roles of management accountants: A comparative analysis between dependent and independent organizations. Journal of Accounting \& Organizational Change, 1(2), 180-198.

Zainuddin, Z. N., \& Sulaiman, S. (2016). Challenges faced by management accountants in the 21 st century. Procedia Economics and Finance, 37, 466-470. 